\title{
RELATIONSHIP BETWEEN BIG FIVE PERSONALITY TRAITS AND ACADEMIC PERFORMANCE IN MEDICAL STUDENTS
}

Sunita Nighute ${ }^{1}$, S.K. Sadawarte ${ }^{2}$.

\section{HOW TO CITE THIS ARTICLE:}

Sunita Nighute, S.K. Sadawarte. "Relationship between big five personality traits and academic performance in medical students". Journal of Evolution of Medical and Dental Sciences 2014; Vol. 3, Issue 17, April 28;

Page: 4446-4452, DOI: $10.14260 /$ jemds/2014/2457

ABSTRACT: It is often argued that a blend of personality characteristics is necessary for people to be successful in their career. Educators, researchers, and psychologists have been constantly searching for parsimonious set of variables that predicts patterns of students' behaviours and their relationship to academic achievement so this study was done to find out the relationship between Big Five personality traits and academic achievement in an undergraduate medical students $(n=150)$ .In this study All personality traits are positively and significantly predicted students overall grade except Extraversion. Of all traits Openness and Neuroticism were positively related to student's academic achievement than agreeableness and conscientiousness and are more important predictors of overall grade of the students. Extraversion was positively related ( $\mathrm{r}=.150$ ) but not statistically significant. The present results provide evidence supporting the Relationship between Personality Traits and Academic Performance in medical students.

KEYWORDS: Personality Traits; Big Five; Academic performance, medical students.

MESHTERMS: Personality traits, academic performance.

INTRODUCTION: This paper explores the degree to which personality predict academic performance (AP). In doing so, it attempts to assess the incremental validity of learning in the students. Students differ in their personal values; they receive and process information differently; their personality trait is different and hence, so also is their understanding. College students tend to prefer learning environments consistent with their own personality type preference.

- Approaches over and above measures of personality which is not only the most wellestablished predictors of academic performance, but also the most general and widely explored constructs of differential psychology. Many scholars have accepted five-factor model of personality as a replicable and unifying taxonomy of personality ${ }^{1}$ and have found personality traits to be significantly related to successful job and school performance, both logically and statistically ${ }^{2,3}$ But there is a lack of adequate research about the role of personality as a predictor of achievement in the medical students. The purpose of this study is, therefore, to examine the impact of personality type on the academic performance of students in the medical college using five-factor model of personality.

\section{AIMS:}

1. To investigate the relationship between Five Factor Model of Personality (FFM) and students' performance in medical college.

2. To find out which specific personality traits predict medical student's performance in their medical course. 
STUDENT'S PERSONALITY TRAITS: The Big-5 (Five-factor model of personality) has been developed after years of testing by factor-analyzing a large number of personality traits. The Big Five model was commonly derived from work by Cattell et al (1970) $)^{4}$. The Big -5 are commonly used because they combine the best of Cattell's (1970) comprehensive list of personality traits with the best of Eysenck's $(1991)^{5}$ concise list. They are

$\begin{array}{ll}\text { Extroversion } & - \text { Introversion } \\ \text { Neuroticism } & - \text { Stability } \\ \text { Agreeableness } & - \text { Antagonism } \\ \text { Conscientiousness } & - \text { Undirectedness } \\ \text { Openness } & - \text { Non-openness }\end{array}$

Extroversion: Extraverts are usually sociable, talkative and communicative, and friendly. They are described as active, bold, assertive, exciting, and stimulating.6,1 Introverts on the other hand tend to be reserved, even-paced and independent. Schniederjan et al7 found extraversion to predict academic success.

Conscientiousness: They are organized, exacting, disciplined, diligent, dependable, methodical, and purposeful and has been linked to educational achievement and particularly to the will to achieve. ${ }^{8}$ It is demonstrated that managers perceive cognitive ability and conscientiousness as the most important attributes related to applicants hirability ${ }^{9}$. De Fruyt \& Mervielde, ${ }^{10}$ Blickle $^{11}$ has demonstrated that conscientiousness is related to learning outcome mediated by learning strategies. Conscientious students are good at organizing their work, managing their time and studying hard with clear goals. ${ }^{12}$ They have an intrinsic motivation and a positive attitude. ${ }^{13}$ Students low in conscientiousness tends to be less careful, less focused and more likely to be distracted from tasks.

Agreeableness: Agreeableness or likeability ${ }^{14}$ refers to such traits as selflessness, goodnatured, gentle, co-operative, flexible, tolerance, generous, sympathetic, courteous, striving for common understanding, and maintaining social affiliations.

Goldberg ${ }^{1}$ found Agreeableness to be associated with tendencies toward kindness, unselfishness, generosity, and fairness. Students low in agreeableness tends to be more aggressive and less cooperative.

Neuroticism: The individuals who score high on neuroticism tend to experience effects such as fear, sadness, embarrassment, disgust and anger. Those who score low in this area are usually calm, even-tempered and relaxed at work and in their personal lives. Strong relationships were found between the emotional intelligence dimensions (empathy, autonomy, and emotional control) and the big five, particularly with extraversion and emotional stability. ${ }^{15}$ Students learn better when they are in the company of members of their species other than themselves ${ }^{7}$

Openness to experience: These individuals feel both the good and the bad deeply ${ }^{16}$. While neuroticism entails anxiety and depression 6 , Openness to experience does not appear to be related to any of the motivational strategies as it entails creativity, sophistication and curiosity ${ }^{17}$.

The past ten years have seen a growing number of studies on the personality correlate of academic achievement. ${ }^{18,19}$ These studies indicate that Conscientiousness is the most significant Correlate of academic achievement, an association that has been explained in terms of the persisting, self-disciplined, and achievement-oriented nature of conscientious students. ${ }^{18}$ Evidence also 
suggests that Openness to Experience, a trait that assesses individual differences in aesthetic interests, creativity, and intellectual curiosity, is positively linked to academic achievement. ${ }^{19}$.

On the other hand, the overlap between Openness and academic achievement has often been interpreted in terms of cognitive ability. Ackerman \& McKenzie ${ }^{20}$ found extraversion to be negatively correlated with success in higher education but found no clear-cut relationship between neuroticism and students' academic achievement. In a study of the relation between personality and academic achievement, Masgrave- Marquart, Bromley, and Dalley ${ }^{21}$ found significant positive correlations between GPA (grade point average) and conscientiousness, openness, and neuroticism. DeRaad and Schouwenburg 22 found that the big five factors of extraversion, conscientiousness, and openness to experience are educationally relevant. Based on the preceding discussion, it is hypothesised that Big Five personality traits are significantly related to students' academic success.

Objectives of this study are-

- To investigate the relationship between Five Factor Model of Personality (FFM) and students' performance.

- To examine which specific personality traits predict medical students' performance.

MATERIALS AND METHODS: This study was conducted in the people's medical college and research centre, Bhopal (mp).We collected data from 150 students of first MBBS 2011-2012 batch. Of these individuals, $85 \%$ were males and $65 \%$ were females. Demographic information such as age, gender was collected, at the end of the 2011-2012 academic year we also collected final numeric student grades in the course.

Inclusion criteria was 150 healthy medical students of first MBBS batch 2011-2012,

Exclusion criteria- Students who are having any major illness were excluded from the study.

Ethical clearance was taken from institutional ethical committee and written consent was taken from the students of first MBBS those who are involved in the study.

At the start of the semester during classes a personality inventory was administered to the students. We used personality inventory questionnaire of Buchanan (2001) based on Five-Factor Modality (FFM). The students rated each item on a 5-point Likert-type scale (1= strongly disagree, 5 = strongly agree). The FFM is based in a belief that people are rational beings and count for their own personality and behaving, can analyze their own actions and reactions (McCrae \& Costa, 1996).

At the end of 2011-2012 academic year, after the final examination result achievement grades of all the subjects of the students who filled in the questionnaire were obtained. Achievement grades were summed and total obtained was divided into the number of subjects in the first MBBS course.

We used students' grades $(D=1 ; C=2 ; B=3$, and $A=4)$ to measure students academic achievement. Then data is calculated and analysed by using various statistical methods.

RESULTS: Table 1 presents the personality scales and academic achievement. The table shows the mean of student's academic achievement and the means of their personality traits (agreeableness, conscientiousness, openness, extroversion, and neuroticism) and Pearson correlation that shows the relations between the dependent variable (grade) and independent variables (students' personality traits). 
According to the findings, all personality traits were found to be significantly correlated to student's academic achievement except extraversion. However, though not statistically significant, there is a positive correlation between extroversion and students' grade $(r=.150)$.

Table 2 shows Relationships between Personality Traits and Students' Academic Performance Regression results .regression analysis was done to find out the influence of the students personality traits and academic achievement. Significant effect was observed for personality traits and academic achievement.

DISCUSSION: Personality traits are expressed in learning styles, which are, in turn, reflected in learning strategies and eventually produce a learning outcome.e ${ }^{22}$ Therefore, an understanding of the students' personality traits will benefit both students and teachers.

The present paper has attempted to explore the predictability of academic performance in medical course by well-established personality measures the five factor model ${ }^{6}$. The five-factor model of personality can provide a useful framework for examining the relationship between personality constructs and students' performance in the medical course.

The results of this study support the hypothesis that personality is significantly related to academic performance. 232224 In this study regression analysis reveal that openness, and neuroticism are more important predictors of students academic performance than conscientiousness and agreeableness and is in consistent with the study of Mohammed Chowdhury (2006). ${ }^{25}$

Also there is positive but not statistically significant correlation between students academic achievement and the psychological type of extraversion(r=.150) supporting the study of Mohammed Chowdhury. ${ }^{25}$ As extraverted students engaged in more social and impulsive activities, and spent few hours a day in studying.

as per previous research of Cattell \& Kline ${ }^{26}$ Neuroticism was found to be an important predictor of academic performance Further, as Furnham and Mitchell (1991) ${ }^{27}$ suggested, this correlation may be associated with anxiety characteristics of neurotic personalities.

Consistent with the previous literature Blickle; ${ }^{23}$ Costa \& McCrae, ${ }^{6}$ De Raad \& Schouwenburg, ${ }^{22}$ Goff \& Ackerman, ${ }^{24}$ Conscientiousness was found to be the important Correlate and predictor of academic performance. The positive association between Academic performance and Conscientiousness may be simply attributed to the hard-working, organised and ambitious nature of highly conscientious individuals.

Further, each of the sub-scales of Conscientiousness (i.e., competence, order, dutifulness, achievement striving, self-discipline, and deliberation) can be theoretically related to performance, not only in academic but also in occupational settings. ${ }^{28}$

The five-factor model of personality is useful for examining the relationship between personality constructs and students' performance in the medical course.

Of the five personality constructs under the study, agreeableness is usually expected to have weak relationships with overall performance.

The one situation in which agreeableness appears to have high predictive validity is in students' work that involve considerable interpersonal interactions, particularly when the interactions involve helping, and cooperating with others (e.g. group project assignment, group work in the classroom etc). In the present study agreeableness proved to be significant statistically. 
According to DeYoung, Peterson \& Higgins ${ }^{29}$, Openness reflects increased level of dopaminergic function and is related to the functions of the dorsolateral prefrontal cortex. This has been the basis for asserting a link between Openness and IQ. Future research is, therefore, needed to examine the effects of these on students' personality and performance it is believed that personality inventories should not be neglected in any academic selection process, for individual differences in personality are probably of educational relevance in higher learning programmes. The personality traits in this study have been considered independently in the prediction of performance in medical students. Clearly academic performance (AP) and the personality variables we included did not explain all of the variance in grades and it is interesting to speculate as to what other factors might be important. Future research may want to assess the impact of family factors, school environment, peer influences, and personality factors not studied here. These could include self-discipline, motivation, intellectual engagement, and self-perceived ability.

\section{REFERENCES}

1. Goldberg, L.R. The Development of makers for the big five-factor structure, psychological Assessment, (1992). 4, 26-42.

2. Hogan, J. \& Hogan, R How to measure employee reliability. J of App Psych (1989). 74(2), 273279.

3. Day, D. and Silverman, S. Personality and Job performance: Evidence of Incremental Validity: Personnel Psychology (1989). 42(1), 25-36.

4. Cattell, R.B., Eber H.W., and Tatsuka, M.M. The handbook of the sixteen-personality factor questionnaire. Champaign, IL: Institute for Personality and Ability Testing. (1970).

5. Eysenck, HJ. Dimensions of personality: criteria for a taxonomic paradigm. Personality and Individual Diff, (1991). 12: 773-90.

6. Costa, T and McCrae, R.R. Normal personality assessment in clinical practice: The NEO Personality Inventory. Psychological Assessment (1992) 4, 5-13.

7. Schniederjan, Marc J; Kim, Eyong B; Relationship of student undergraduate achievement and personality characteristics in a total web-based environment: An empirical study, J of Innovative Education (2005), vol 3, number 2; PP 205-221.

8. Howard, J \& Howard, M. An introduction to the five-factor model of personality for human resource professionals. (1998). Available on: www.centacs.com/quik-pt3.htm, site accessed 7.6.1999.

9. Mount, M \& Barrick, M. The Big five personality dimensions: Implications for research and practice in human resource management. Research in Personnel and Human Resource Management (1995). 13, 153-200.

10. DeFruyt \& Mervielde, Personality and interests as predictors of educational streaming and achievement. European J of Personality, (1996) 10, 405-425.

11. Blickle, G. Personality traits, learning strategies, and performance European J of Personality, (1996).10, 337-352.

12. Entwistle, N \& Tait, H. Approaches and study skills inventory for students. Centre for Research on Learning and Instruction. University of Edinburgh. (1996).

13. Entwistle, N. Motivational factors in students' approaches to learning in: Learning strategies and learning styles. In R.R. Schmeck (Ed) New York: Plenum Press. pp. (1988) 21-49. 
14. Hogan. A psychoanalytic perspective on the five-factor model of personality. In J.S. Wiggins (Ed.), the five-factor model of personality (pp. 163-179). New York: Guildford Press. (1996).

15. Karen, K; Thisjs M; Schakel, L The relationship of emotional intelligence with academic intelligence and the Big- Five, European j of Personality, (2002). vol. 16, number 2, March/April

16. Cooper, S.E., and Miller, J.A. MBTI learning style-teaching style discongruencies, Educational and Psychological Measurement, (1991).51, 699-707.

17. Barrick, M.R. and Mount, M.K. The Big Five personality dimensions and job performance: A meta-analysis. Personnel Psychology (1991) 44, 1-26.

18. Chamorro-Premuzic, T, \& Furnham, A. A possible model for explaining the personalityintelligence interface. British J of Psychology (2004), 95, 249-264.

19. O'Connor, M., \& Paunonen, S. Big Five personality predictors of post-secondary academic performance. Personality and Individual Differences, (2007) 43, 971-990.

20. Ackerman, P. L., \& Heggestad, E. D. Intelligence, personality and interests: Evidence for overlapping traits. Psychological Bulletin, (1997) 121, 219-245.

21. Musgrave- Marquart, D., Broomley, S.P., and Dalley, M.B. Personality, academic attribution and substance use as predictors of academic achievement in college students. J of Social Behaviour and Personality, (1997) 12, 501-511.

22. De Raad, B. \& Schouwenburg, C. Personality in learning and education: a review. European J of Personality, (1996) 10, 303-336.

23. lickle, G. Personality traits, learning strategies, and performance European J of Personality, (1996) 10, 337-352.

24. Goff, M., \& Ackerman, P. Personality-intelligence relations: Assessment of typical intellectual engagement. J of Educational Psychology (1992) 84, 537-552.

25. Mohammed Chowdhury, Students' Personality Traits and Academic Performance: A FiveFactor Model Perspective, College Quarterly of Seneca College (2006) Volume 9 Number 3 .

26. Cattell, R., \& Kline, P. The scientific analysis of personality and motivation. New York: Academic Press. (1977).

27. Furnham, A., \& Mitchell, J. Personality, needs, social skills and academic achievement: A longitudinal study. Personality and Individual Differences, (1991)12, 1067-1073.

28. Mount, M., \& Barrick, M. The big five personality dimensions: Implications for research and practice in human resources management. In G. Ferris (Ed.), Research in personnel and human management: (1995). Vol. 13 (pp. 153-200). Greenwich, CT: JAI Press.

29. DeYoung, Peterson and Higgins. (2005). Sources of Openness/Intellect: Cognitive and Neuropsychological Correlates of the Fifth Factor of Personality, Journal of Research in Personality, 73: 825-258. 


\section{ORIGINAL ARTICLE}

\section{RESULTS:}

TABLE 1: Statistics of personality Scales and Grade (Academic performance) and Pearson Correlation among the variables.

\begin{tabular}{|l|c|c|c|c|c|c|c|c|}
\hline & Mean & SD & Agree & Cons & Open & Extra & Neuro & Grade \\
\hline Agree & 3.43 & 0.50 & 1 & $0.445^{* *}$ & $0.646^{* *}$ & $0.362^{* *}$ & $0.560^{* *}$ & $0.240^{* *}$ \\
\hline Cons & 22.78 & 4.36 & $0.445^{* *}$ & 1 & $0.570^{* *}$ & $0.504^{* *}$ & $0.576^{* *}$ & $0.227^{* *}$ \\
\hline Open & 30.53 & 6.62 & $0.646^{* *}$ & $0.570^{* *}$ & 1 & $0.300^{* *}$ & $0.664^{* *}$ & $0.280^{* *}$ \\
\hline Extra & 24.34 & 6.5 & $0.362^{* *}$ & $0.504^{* *}$ & $0.300^{* *}$ & 1 & $0.298^{* *}$ & 0.150 \\
\hline Neuro & 30.60 & 5.37 & $0.560^{* *}$ & $0.576^{* *}$ & $0.664^{* *}$ & $.298^{* *}$ & 1 & $0.232^{* *}$ \\
\hline Grade & 21.27 & 4.36 & $0.240^{* *}$ & $0.227^{* *}$ & $0.280^{* *}$ & 0.150 & $0.232^{* *}$ & 1 \\
\hline
\end{tabular}

** significant $<0.01$ level .

TABLE 2: Relationships between Personality Traits and Students' Academic Performance Regression results.

\begin{tabular}{|l|c|c|}
\hline Personality Traits & $\begin{array}{c}\text { Academic Performance } \\
\text { (grade) }\end{array}$ & Significance Level \\
\hline Agreeableness & .240 & .005 \\
\hline Conscientiousness & .227 & .006 \\
\hline Openness & .280 & .001 \\
\hline Extraversion & .150 & .113 \\
\hline Neuroticism & .232 & .001 \\
\hline
\end{tabular}

\section{AUTHORS:}

1. Sunita Nighute

2. S. K. Sadawarte.

\section{PARTICULARS OF CONTRIBUTORS:}

1. Associate Professor, Department of Physiology, Peoples Medical College and Research Centre, BHOPAL Madhya Pradesh.

2. Professor, Department of Physiology, Peoples Medical College and Research Centre, BHOPAL Madhya Pradesh.

NAME ADRRESS EMAIL ID OF THE CORRESPONDING AUTHOR:

Dr. Sunita Nighute,

HIG-B-6, PCMS \& RC,

Bhanpur, BHOPAL,

Madhya Pradesh- 462037.

E-mail: drsunitanighute@gmail.com

Date of Submission: 29/06/2013.

Date of Peer Review: 29/06/2013.

Date of Acceptance: 01/07/2013.

Date of Publishing: 22/04/2014 